\title{
NEFORMALIAJAM SUAUGUSIŲJŲ VERSLUMO UGDYMUISI SKIRTŲ MOKYMOSI PRIEMONIŲ PRIEINAMUMAS
}

\author{
Romas Prakapas \\ Mykolo Romerio universitetas \\ Socialinių technologijų fakultetas \\ Edukologijos ir socialinio darbo institutas \\ Ateities g. 20, LT-08303 Vilnius, Lietuva \\ Tel. (+370 5) 2714710 \\ Elektroninis paštas prakapas@mruni.eu \\ Jolanta Devenytè \\ Mykolo Romerio universitetas \\ Socialinių technologijų fakultetas \\ Edukologijos ir socialinio darbo institutas \\ Ateities g. 20, LT-08303 Vilnius, Lietuva \\ Tel. (+370 5) 2714710 \\ Elektroninis paštas jolanta.jd@gmail.com
}

Pateiktas 2014 m. gegužès 20 d., parengta spausdinti 2014 m. spalio 10 d.

doi:10.13165/SMS-14-6-2-09

Anotacija. Atsižvelgiant ị Lietuvoje dažniausiai vykdomus su verslumo ugdymu(si) susijusius tyrimus, kurie dažniausiai orientuojami i formaluji ugdyma, straipsnyje nagrinejjamas neformalusis suaugusiuju verslumo ugdymosi reiškinys. Lietuvoje dešimtmetį vykdant kryptingus su suaugusiuju švietimu susijusius tyrimus, yra konstatuotos pagrindinès problemos (finansavimas, kokybès užtikrinimas, andragogu kompetencijos ir pan.) siejamos iš esmès tik su išoriniais ugdymo proceso veiksniais, tuo tarpu vykdomos 
edukacinès veiklos ir ju analizès rodo bütinybę nagrinèti pačiu suaugusiujų ugdymąsi ir tam sudaromas galimybes. Viena ju - suaugusiuju verslumo ugdymuisi skirtu priemoniu prieinamumas. Straipsnio tikslas - atskleisti neformaliajam suaugusiuju verslumo ugdymuisi skirtu mokymosi priemoniu prieinamuma Lietuvoje.

Straipsnyje pristatomi $2013 \mathrm{~m}$. spalio-lapkričio mèn. atlikto empirinio tyrimo rezultatai. Tyrimo metodas - apklausa žodžiu (interviu). Tyrimo priemoné parengta dokumentu ir mokslinès literatūros analizès, padejusios išsiaiškinti neformaliojo suaugusiujų švietimo padeti Lietuvoje, pagrindu. Tyrimo dalyviai $(n=5)$ - andragogai, aktyviai dalyvaujantys suaugusiujų neformaliajame švietime bei vykdantys kryptingus mokslinius suaugusiujų švietimo tyrimus. Straipsnio pabaigoje pristatomi pagrindiniai tyrimo rezultatai ir išvados.

Reikšminiai žodžiai: neformalusis suaugusiuju švietimas, mokymosi priemonès, verslumo ugdymasis.

\section{Ivadas}

Technologijų kaita, žinių gausa, gyvenimo intensyvumas tarsi ịpareigoja asmenị nuolat tobulèti, ugdytis kompetencijas. Kompetentingas asmuo yra patrauklus darbo rinkoje, o tokius darbuotojus turinti organizacija yra konkurencinga, atitinkamai aukštesnis visuomenès išsilavinimo lygis ir didesnè tokios visuomenès gerovè. Verslumas, kaip visiems aktuali kompetencija, siejama su kūrybingumu, išradingumu, naujomis idejomis ir jų igyvendinimu, todèl verslumo ugdymasis, anot tyrèjų ${ }^{1}$, igyja vis didesnę reikšmę socialinių, ekonominių ir technologinių pokyčių sąlygomis. Europos Sąjungos dokumentuose ${ }^{2}$ akcentuojama verslumo ugdymo svarba bei mokymosi visą gyvenimą būtinybè. Šiandien Lietuvoje formalizuotas verslumo ugdymas integruojamas ị vidurinio ugdymo bendrąsias programas, skatinamas besimokančiųjų savarankiškumas, saviraiška, pasitikejjimas, atsakingumas, bendravimas, bendradarbiavimas.

Lietuvoje jau atliekami kryptingi, konkretūs, su verslumo ugdymu susiję tyrimai, tiesa, jie orientuoti dažniausiai ị formalųji ugdymą (pvz., A. Župerka ${ }^{3}$ ), atskleidè, kad mokyklose iki 2009 m. nebuvo metodinių priemonių, vadovèlių verslumo ugdymui, kad pedagogai stokojo verslumo ugdymo kompetencijų; A. Jelagaitè, V. Lukoševičius $^{4}$ pažymi, jog dauguma pedagogų supranta, kaip svarbu ugdyti verslumą, tačiau

1 Dudaitè, J.; Žibènienè, G. Verslumo edukologijos studijų programą igyvendinančių dèstytojų samprata apie verslumą ir verslumo ugdymą. Socialinis darbas. 2012, 11(1); Pruett, M. Entrepreneurship Education: Workshops and Entrepreneurial Intentions. Journal Of Education For Business. 2012, 87(2) ir kt.

2 Mokymosi visa gyvenima memorandumas. Vilnius: Lietuvos Respublikos švietimo ir mokslo ministerija, Lietuvos suaugusiųjų švietimo asociacija, 2001 ir kt.

3 Župerka, A. Moksleivių verslumo ugdymo tobulinimo kryptys Lietuvoje. Verslas, vadyba ir studijos. Vilnius: Technika, 2009.

4 Jelagaitè, A.; Lukoševičius, V. Mokinių verslumo ugdymas bendrojo ugdymo mokykloje: mokytojų požiūris. Pedagogika. 2011, 104. 
tik nedaugelis verslumo ugdymą integruoja ị dèstomą dalyką, nes pedagogai jaučiasi neturintys verslumo ugdymui reikiamų kompetencijų ir t. t.). Vertinant neformalųji ugdymą, ir ypač suaugusiųjų, kyla kitos problemos. Nepaisant to, kad suaugusiųjų švietimo klausimai plačiai nušviečiami ${ }^{5}$, tačiau Lietuvoje atliekami tyrimai rodo, kad suaugusiųjų švietimas dažniausiai siejamas tik su profesinių igūdžių tobulinimu 6 . Be to, mokymosi visą gyvenimą kontekste neformalusis suaugusiųjų švietimas yra vertinga mokymosi forma ${ }^{7}$, o tai kartu yra reikšmingas socializacijos veiksnys ${ }^{8}$. Paminètina ir tai, kad nuo $2004 \mathrm{~m}$. Lietuvoje kryptingai atliekami ịvairūs suaugusiųjų švietimo problemų tyrimai9 ${ }^{9}$, kuriuose išskirtinai aptariamos problemos, siejamos su

Bukina, N. N. Stanovlenie sistemy neformalnogo obrazovanie sistemy vzroslykh. Chelovek $i$ obrazovanie. 2006, 7; Knowles, M. S.; Holton, E. F.; Swanson, R. A. Suaugęs besimokantysis: klasikinis požiūris ị suaugusiujų švietimą. Vilnius: Danielius, 2007; Schmidt, S. W. Case Studies And Activities In Adult Education And Human Resource Development. Charlotte: Information Age Pub, 2010; Plakhotnik, M.; Rocco, T. Implementing Writing Support Circles with Adult Learners in a Nonformal Education Setting: Priority, Practice, and Process. Adult Learning. 2012, 23(2) ir kt.

6 Žemaitaitytè, I. Neformalusis suaugusiųu švietimas: plètros tendencijos dabartinèje Europoje. Vilnius: MRU leidykla, 2007; Trakšelys, K. Suaugusiųjų švietimo tyrimų 2004-2011 metų analizè. Socialinių mokslų studijos. 2012, 4(4); Butvilienė, J. Neformalusis suaugusiųjų švietimas: valstybinis ir privatus mokymo sektoriai. Acta Paedagogica Vilnensia. 2013, 30.

7 Linkaitytė, G. M.; Žilinskaitè, L. Mokymosi visą gyvenimą idèjos ịgyvendinimo perspektyva Lietuvoje. Pedagogika. 2008, 89; Rutkienè, A.; Trepulè, E. Nuotolinis suaugusiųjų mokymas(is) mokymosi visą gyvenimą kontekste. Acta Paedagogica Vilnensia. 2009, 23; Mukhlaeva, T. V. Mezhdunarodnyj opyt neformalnogo obrazovanie, 2010 [interaktyvus]. [žiūrèta 2014-01-21]. $<$ http://inovrao.ru>; Butvilienė, J. Suaugusiųjų neformaliojo švietimo socialinis kontekstas. Filosofija, Sociologija. 2011, 22(4).

8 Žemaitaityte, I., op cit. 6.

9 Suaugusiųjų mokymasis Lietuvoje: aprèptis, poreikiai ir pasiūla, 2006 [interaktyvus]. [žiūrèta 2014-01-21]. <http://www.suaugusiujusvietimas.lt/lt/suaugusiuju-svietimo-bukle/>; Suaugusiųjų mokymosi motyvacija ir poreikiai Lietuvoje, Latvijoje, Estijoje ir Suomijoje, 2010 [interaktyvus]. [žiūrèta 2014-01-21]. <http://www.upc.smm.lt/svietimas/tyrimai/>; Suaugusiųju švietimo organizavimo būklè savivaldybèse, 2006 [interaktyvus]. [žiūrèta 2014-01-21]. <http:// www.upc.smm.lt/ svietimas/tyrimai/>; Suaugusiųjų tęstinio mokymo galimybių plètra mokymosi visą gyvenimą strategijos igyvendinimo kontekste, 2004 [interaktyvus]. [žiūrèta 2014-01-21]. <http://www.upc.smm.lt/svietimas/tyrimai/>; Taikomasis suaugusiųjų švietimo tyrimas, 2011 [interaktyvus]. [žiūrèta 2014-01-21]. <http://www.suaugusiujusvietimas. 1t/ lt/suaugusiuju-svietimo-bukle/>; Trečiojo amžiaus universitetų sistemos veiklos analizé, 2012 [interaktyvus]. [žiūrèta 2013-11-21]. <http://www.upc.smm.lt/ svietimas/tyrimai/>; Neformaliojo suaugusiųjų švietimo plètra: Valstybès kontrolès valstybinio audito ataskaita, 2013 [interaktyvus]. [žiūrèta 2013-09-25]. <http://www.vkontrole.lt/ audito_ataskaitos. aspx?tipas=2>; Neformaliojo suaugusiųjų švietimo plètra Lietuvoje: finansavimo alternatyvų analizè, 2007 [interaktyvus]. [žiūrèta 2013-05-28]. <http://www.smm.lt/svietimo_bukle/ docs/tyrimai/es/VPVI\%20studija\%20Neformalusis\%20svietimas.pdf $>$; Neformaliojo suaugusiųjų švietimo būklè ir gyventojų bei darbdavių požiūris ị neformalụjị suaugusiųjų švietimą, 2005 [interaktyvus]. [žiūrèta 2014-01-21]. <http://www.upc.smm.lt/svietimas/ tyrimai/>; Neformaliojo suaugusiųjų mokymosi sampratų analizė mokymosi visą gyvenimą kontekste, 
neformaliojo suaugusiųjų švietimo sistemos finansavimu, neformaliojo suaugusiųjų švietimo kokybès užtikrinimu, suaugusiųų švietejų kompetencijomis, informacijos apie mokymus sklaida ir pan. Minètų tyrimų rezultatų analizė rodo, kad stokojama verslumo ugdymo mokymų suaugusiesiems. $2011 \mathrm{~m}$. atliktas tyrimas ${ }^{10}$ atskleidè ryši tarp suaugusiųjų dalyvavimo verslumo mokymuose su jų uždirbamomis pajamomis, t. y. kad verslumo mokymuose dažniau dalyvauja didesnes pajamas gaunantys šalies gyventojai, o tai paprastai asmenys, igiję aukštesnị išsilavinimą. Visa tai tiesiogiai siejasi su konkrečių mokymosi priemonių egzistavimu ir fiziniu prieinamumu kiekvienam, siekiančiam ugdyti savo verslumo kompetenciją. Taigi, minèti tyrimai neatskleidžia priežasčių: kodèl pedagogams trūksta kompetencijos verslumo ugdymo klausimais, kodèl daugiausia neformalusis suaugusiųjų švietimas siejamas tik su kvalifikacijos tobulinimu, kaip formuoti neformaliojo suaugusiųjų švietimo sistemą su reikiamu finansavimu, užtikrinant neformaliojo suaugusiųjų švietimo kokybę, suaugusiųjų švietejjų kompetencijas, keičiant požiūrị i neformalųjị suaugusiųjų švietimą valstybès lygiu. Minèti klausimai suponuoja nuomonę, kad valstybės mastu nèra sistemingai formuojamas požiūris dèl neformaliojo suaugusiųjų verslumo ugdymosi poreikio, galimai nèra neformaliajam suaugusiųų verslumo ugdymuisi skirtų mokymosi priemonių. Atsižvelgiant ị šiuos probleminius klausimus straipsnyje nagrinèjama neformaliajam suaugusiųjų verslumo ugdymuisi skirtų mokymosi priemonių prieinamumo problema.

Objektas - neformaliajam suaugusiųjų verslumo ugdymuisi skirtų mokymosi priemonių prieinamumas.

Tikslas - atskleisti neformaliajam suaugusiųjų verslumo ugdymuisi skirtų mokymosi priemonių prieinamumą Lietuvoje.

Metodai. Dokumentų, mokslinès literatūros bei empirinių tyrimų rezultatų analizė, siekiant išsiaiškinti teisinę bazę bei neformaliojo suaugusiųjų švietimo padètị Lietuvoje. Andragogų, susijusių su neformaliuoju suaugusiųjų verslumo ugdymusi, apklausa (interviu), siekiant išsiaiškinti neformaliojo suaugusiųjų švietimo situaciją, neformaliajam suaugusiųų verslumo ugdymuisi skirtų mokymosi priemonių ịvairovę, populiarumą, galimybes naudotis.

\section{Suaugusiųjų verslumo ugdymasis}

Verslumo ugdymosi sẻkmingumas iš dalies priklauso nuo to, kaip suvokiama, kas yra verslumas. Svarbu pažymėti, kad šiandien moksle nėra vienos nuomonès šiuo klausimu. Vieni autoriai ${ }^{11}$ verslumą apibūdina kaip kūrybinị mąstymą, naujos idejos

2011 [interaktyvus]. [žiūrèta 2014-01-21]. <http://www.upc.smm.lt/svietimas/tyrimai/>; Kaimuose ir miestuose (gyventojų skaičius iki 30000 ) gyvenančių suaugusiųjų mokymosi poreikiai, 2004 [žiūrèta 2014-01-22]. <http://www.upc.smm.lt/svietimas/tyrimai/>.

10 Taikomasis suaugusiųjų švietimo tyrimas, 2011 [interaktyvus]. [žiūrèta 2014-01-21]. <http:// www.suaugusiujusvietimas. lt/lt/suaugusiuju-svietimo-bukle/>.

11 Strazdienè, G.; Garalis, A. Verslumas: ugdymo programos ir jų efektyvumo raiška. Organizacijų vadyba: sisteminiai tyrimai. 2006, 38; Clair, R.; MacLachlan, K.; Tett, L. Educational 
igyvendinimą, o kiti ${ }^{12}$ - verslumu ịvardija ne vien norejjimą, bet ir mokèjimą, galëjimą novatoriškai mąstyti ir aktyviai veikti visose gyvenimo situacijose.

Verslumo sampratos skirstomos ir pagal tai, ar verslumu laikoma pridètinès ekonominès vertès kūrimas, o tam reikalingos specialios kompetencijos, ar verslumas yra asmens savybès ir gebejjimai, padedantys sèkmingai funkcionuoti visuomenejje ${ }^{13}$. Pasak C. Turnerio ${ }^{14}$, verslumas tai „savanoriškas bendras darbas, rizikavimas, kūrimas, igyvendinimas, gebèjimas iškelti ir sèkmingai diegti novatoriškas idejjas, kuriomis siekiama kuo plačiau panaudoti galimybes neapsiribojant esamais modeliais, struktūra ir ištekliais“.

Apibendrinant skirtingų autorių ${ }^{15}$ nuomones, galima teigti, kad verslumas siejamas su savęs pažinimu, pasitikejjimu savimi, savarankiškumu, kūrybingumu, iniciatyvumu, gebejjimu analizuoti problemas ir priimti sprendimus, gebejimu bendrauti, bendradarbiauti, planuoti, gebejjimu siekti užsibrèžto tikslo, mokejjimu ịvertinti savo galimybes ir apskaičiuotai rizikuoti, konfliktų valdymu, kritiniu mąstymu, imlumu naujovėms, komandų sudarymu ir racionaliu jų valdymu bei kitais ịvairiais vadybiniais ịgūdžiais. Todèl suaugusiojo verslumo ugdymasis kaip kompetencija nepriskirtina nei bendrosioms, nei specialiosioms, nes kai kurie minèti požymiai būdingesni bendrosiomis, kai kurie - specialiosiomis kompetencijoms, o kiti - būdingi abiem grupèms.

Akivaizdu, kad suaugusiųjų ugdymosi, t. y. sąmoningo asmens sprendimo ugdymo procese prisiimti ugdytojo funkcijas ${ }^{16}$ (Bitinas, 2011), kontekste verslumo ugdymasis išryškejja per kompetencijas. Mat asmens pokyčiai neatsiejami nuo ịgūdžių, gebejjimų, îvairių kompetencijų ugdymosi.

\section{Suaugusiųjų įsitraukimo ị neformalųjị mokymąsi kliūtys}

Lietuvos Respublikos švietimo dokumentuose verslumo apibrězimas yra pateiktas Ekonominio raštingumo ir verslumo ugdymo strategijoje $\mathrm{e}^{17}$ ir apibrèžiamas kaip asmens mąstymo būdas bei asmeninès, socialinès, vadybinès kompetencijos,

entrepreneurs? Practitioner-led action research and the formation of the professional adult literacies instructor. Studies In The Education Of Adults. 2009, 41(2) ir kt.

12 Dudaitè, J.; Žibènienè, G., supra note 1.

13 Gegieckienė, L.; Graikšienė, A. Verslumas. Vilnius: Ciklonas, 2009; Dudaite, J.; Žibènienè, G., supra note 1; Giedrimiené, L. Neformalus suaugusių vartotojų ugdymas. Studies in modern society. 2012, 3(1).

14 Turner, C. Veskite ị sèkmę: kaip sukurti verslias organizacijas. Vilnius: Baltos lankos, 2005.

15 Gegieckienè, L.; Graikšienè, A., supra note 13; Dudaite, J.; Žibènienė, G., supra note; Dačiulytė, R.; Tamulienè, J.; Zablackè, R. Mokymosi visą gyvenimą kompetencijų ugdymasis per neformalụj suaugusiųjų technologijų mokymąsi. Pedagogika. 2010, 97 ir kt.

16 Bitinas, B. Edukologijos terminija: kokybe ir problemos. Klaipeda: Klaipèdos universiteto leidykla, 2011.

17 Ekonominio raštingumo ir verslumo ugdymo strategija. Valstybės žinios. 2004, Nr. 96 -3555. 
leidžiančios turimas žinias pritaikyti savo kasdieniam gyvenimui, tai yra konkretūs gebėjimai, teikiantys galimybę ne tik organizuoti savo verslą, bet ir prisiimti riziką už padarytus sprendimus. Kituose švietimą reglamentuojančiuose teisės aktuose verslumo sąvoka neakcentuojama ir neapibrèžiama, išskyrus Lietuvos Respublikos mokslo ir studijų ịstatymą ${ }^{18}$, kuriame nurodomas tikslas ugdyti verslią asmenybę. Tuo tarpu naujausiame strateginiame valstybės dokumente Lietuvos pažangos strategijoje „Lietuva $2030^{“ 19}$ akcentuojama sumani ekonomika, kuri grindžiama verslumu, o verslumas prilyginamas kūrybingumui.

Lietuvos Respublikos neformaliojo suaugusiųjų švietimo įstatyme ${ }^{20}$ teigiama, kad neformaliojo suaugusiųjų švietimo tikslas yra padèti igyvendinti igimtą žmogaus teisę visą gyvenimą ugdyti savo asmenybę, laiduoti asmeniui galimybę igyti žinių ir gebẻjimų, kurių jam reikia kaip demokratinès visuomenės piliečiui ir tam tikros profesijos specialistui, prisidèti prie kūrybingo ir prasmingo laisvalaikio.

Tačiau 2013 metų audito ataskaita ${ }^{21}$ rodo, jog tikslo igyvendinimui i mokymus turètų būti ịtraukiama didesnè šalies gyventojų dalis, nes pastaruoju metu aktyviau mokosi jaunesni, turintys aukštąji išsilavinimą, daugiau uždirbantys, gyvenantys miestuose gyventojai. Tai galimai susiję su aukštesniu pragyvenimo lygiu, be to, daugiau finansinio dèmesio skiriama valstybès remiamam formaliajam švietimui, didžia dalimi apsiribojama vien Europos Sąjungos projektų bendru finansavimu ir mažai taikoma tiesioginių neformaliojo švietimo paklausos finansavimo mechanizmų, galinčių paskatinti neformaliojo švietimo plètrą šalyje ir pan. ${ }^{22}$

Kita kliūtis - pačių suaugusiųjų motyvacijos stoka. Kaip žinoma, suaugusiuosius motyvuoja vidiniai ir išoriniai veiksniai. Vidiniams veiksniams, motyvuojantiems suaugusiuosius mokytis, priskirtina: vertybinès orientacijos, savęs pažinimas, saviraiškos ir bendravimo poreikis, galimybe išspręsti problemas, pagerinti gyvenimo kokybę, ir pan..$^{23}$. Išoriniais motyvuojančiais veiksniais gali būti naujas darbo pasiūlymas, didesnis atlygis, aplinkinių požiūris ir kita ${ }^{24}$. Tačiau suaugusiji veikia ne tik motyvuojantys veiksniai, bet ir veiksniai, suponuojantys suaugusiojo nenorą mokytis

18 Lietuvos Respublikos mokslo ir studijų i̇statymas. Valstybès žinios. 2009, Nr. 54-2140.

19 Valstybès pažangos strategija „Lietuvos pažangos strategija „Lietuva 2030“. Valstybès žinios. 2012, Nr. 61-3050.

20 Lietuvos Respublikos neformaliojo suaugusiųjų švietimo įstatymas. Valstybės žinios. 1998, Nr. 66-1909.

21 Neformaliojo suaugusiųjų švietimo plètra: Valstybès kontrolès valstybinio audito ataskaita, 2013, supra note, 9.

22 Neformaliojo suaugusiųjų švietimo plètra Lietuvoje: finansavimo alternatyvų analizè, 2007, supra note 9.

23 Knowles, M. S.; Holton, E. F.; Swanson, R., supra note 5; Juozaitis, A. M. Pagrindinès kompetencijos andragogų profesineje veikloje. Pedagogika. 2008, 89.; Butviliené, J. Neformalusis suaugusiųjų švietimas: valstybinis ir privatus mokymo sektoriai. Acta Paedagogica Vilnensia. 2013, 30.

24 Knowles, M. S.; Holton, E. F.; Swanson, R. A., supra note 5; Butvilienė, J., supra note 7. 
(nepasitikejjimas savimi, sveikatos problemos, neigiama mokyklinè mokymosi patirtis, mokymosi kaštai, netinkamas mokymosi laikas, netinkama mokymosi vieta, neigiamas aplinkos požiūris ị suaugusiojo mokymąsi ir pan.). Tyrimų duomenys ${ }^{25}$ rodo, jog per pastaruosius 12 menesių respondentai dažniausiai savarankiškai kryptingai mokèsi iš knygų, interneto, vaizdo ir garso įrašų ir pan., todèl galima teigti, jog tinkamos mokymosi priemonés prisideda prie suaugusiųjų mokymosi skatinimo.

Mokymo/si priemonès kaip mokymosi proceso struktūros elementai besimokantịji pasiekia ịvairiomis formomis - tekstu, vaizdu, garsu. İvairiuose literatūros šaltiniuose (pvz., Andragogų klausimai ${ }^{26}$ ) pažymima, kad tinkamai parinktos mokymosi priemonès sèkmingai prisideda prie mokymosi tikslų pasiekimo. Dažniausiai išskiriamos naudojantis informacinemis technologijomis pateikiamos vaizdinès priemonès, kai besimokantysis gali ne tik pasyviai stebėti vaizdo įrašus, nagrinèti informacinius tekstus, bet ir aktyviai dalyvauti virtualiose diskusijose, vaizdo treniruotèse ir pan.

Bèda ta, kad teoriškai aprašytos įvairios mokymo/si priemonès ir jų sąsajos su motyvacijos stiprinimu menkai analizuojamos ir aktualizuojamos neformaliojo suaugusiųjų mokymosi kontekste.

\section{Tyrimo dalyvių charakteristikos ir tyrimo duomenų analizė}

Tyrimo imtis sudaryta remiantis tiksline atranka. Informantų atrankos kriterijus yra išsilavinimas, darbo patirtis. Individualiu pusiau struktūruotu interviu apklausti 5 andragogai - Mykolo Romerio universiteto dèstytojai bei Lietuvos suaugusiųjų švietimo asociacijos nariai. Mykolo Romerio universitetas ir Lietuvos suaugusiųjų švietimo asociacija pasirinkti kaip suaugusiųjų edukacinę veiklą aktyviai vykdančios institucijos, kurių atstovai aktyviai dalyvauja ne tik neformaliajame suaugusiųjų švietime, bet ir vykdo kryptingus mokslinius suaugusiųjų švietimo tyrimus.

Informantų amžius nuo 40 iki 60 metų. Interviu atliktas 2013 metų spalio-lapkričio mènesiais, informantų darbovietėse, iš anksto su jais suderintu, informantams patogiu metu. Visiems informantams buvo pristatytas tyrimo tikslas, gauti visų informantų sutikimai įrašyti pokalbius ị diktofoną. Interviu vidutiniškai truko apie 1 val.

Paisant tyrimo etikos reikalavimų ir siekiant užtikrinti tyrimo dalyvių asmeninès informacijos konfidencialumą, pristatant tyrimo duomenis informantų vardai, lytis, tikslus amžius, einamos pareigos niekur neminimi. Kiekvienam informantui tyrejai suteikè individualų kodą (I1 - pirmasis, I2 - antrasis, I3 - trečiasis, I4 - ketvirtasis, I5 - penktasis informantai).

Suaugusiųjų mokymosi motyvacija ir poreikiai Lietuvoje, Latvijoje, Estijoje ir Suomijoje, 2010, supra note 9.

Andragogu klausimai: praktiniai suaugusiujų mokymo aspektai. Vilnius: Lietuvos suaugusiųju švietimo asociacija, 2008. 
Atsižvelgiant ị tai, kad moksle nèra vienos nuomonès verslumo sampratos klausimu, pirmiausia informantų buvo klausiama, kaip jie apibūdintų verslumą. Informantų nuomone, verslumas yra žinios, kurios taikomos praktikoje, taip igyjami verslumo gebejjimai, reikalingi skirtingose žmogaus gyvenimo srityse: asmeninejje, socialinejje („...prisitaikyti kintančioje aplinkoje...“ (I1), „...pritaikyti [...] asmenine, visuomenine, socialine prasme...“ (I2) ir pan.) ar profesinejje („... įsilieti ị darbo rinką,...“ (I1), „,... susikurti savo darbo vietą...“ (I4), „...gebejjimas save parduoti...“ (I2) ir pan.).

Pasak informantų, verslumo kompetencijos yra savęs pažinimas, pasitikèjimas savimi, gebejjimas analizuoti ir priimti sprendimus, kūrybingumas ir aktyvumas. Savęs pažinimas apibūdinamas žinojimu „...ką tu pats gali padaryti...“ (I5), kokias asmuo turi „...stipriąsias puses...“ (I2). Informantų nuomone, asmeniui svarbu tikèti, jog jis gali „...būt verslus“ (I5) ir nebijoti rizikuoti, nes jei „...neišeis šitas dalykas, darysiu kitą..." (I3). Kai asmuo žino, ką jis gali padaryti ir pasitiki savo jègomis, priima sprendimą veikti. Didesnè tikimybè, kad sprendimas bus teisingas, jei bus atlikta aplinkos (rinkos) analizè, nes „...šovė galvon, darysiu! O paskui paaiškèja, kad aplinkai tai to nereikia“ (I5). Svarbu „...analizuoti, ką padariau, kaip padariau, kas iš to išejjo..." (I5), tai yra kritiškai mąstyti. Taigi, verslumas gali būti apibūdintas kaip nestandartinis mąstymas, nes „...ne visi žmonès turi verslumo tą gyslelę...“ (I5), o „... verslume to žmogaus mąstymas turètų būti kitoks..." (I4). Kitas svarbus verslumo sampratos komponentas - darbas - „...kur tie, kurie šiandien daro ką nors? Kur yra batsiuviai? Kur yra siuvejjai? [...] Kur yra tie žmonės, kur dirba - nèra..." (I3).

Neformaliojo suaugusiųjų verslumo ugdymasis bei tam reikalingų mokymosi priemonių prieinamumas susiję su neformaliojo suaugusiųjų švietimo situacija Lietuvoje, o ją determinuoja teisinė aplinka. Šiuo tikslu buvo teiraujamasi informantų nuomonès apie LR neformaliojo suaugusiųjų švietimo įstatymą (Žin. 1998, Nr.661909) bei šio įstatymo pakeitimą, bandant išgryninti neformaliojo suaugusiųjų švietimo situaciją Lietuvoje. Informantai teigia, kad šiuo metu galiojantis teisès aktas „... pasenęs..." (I2, I5) ir neatitinka „...šių dienų aktualijų“ (I1), jau vien todèl, kad plačiai pasklidusi mokymosi visą gyvenimą idejja, kurios praktinis igyvendinimas „...daugiau atsispindi europiniuose dokumentuose nei Lietuvos dokumentuose arba konkrečiai šiuo įstatymu“ (I2). Akivaizdu, kad teisès aktas, neatitinkantis nūdienos reikmių turètų būti keičiamas. Naujasis teisès akto keitimo projektas bando įteisinti nuostatą, jog kiekvienam suaugusiajam nustatyta tvarka būtų skiriamos tam tikros lěšos neformaliajam mokymuisi, galimai taip išsprendžiant suaugusiojo mokymosi motyvacijos problemą. Mat ne visi suaugusieji ị mokymus eina suprasdami, kad jiems to reikia. Čia motyvai labai ịvairūs: darbo biržos siuntimu ị mokymus einama dèl to, kad „gauna labai gerą stipendiją..." (I3), „... gauna stipendiją, geresnę negu studentas už mokymus“ (I2); darbdavių nurodymu eina, nes „...aš kaip darbdavys žinau, ko jums reikia, ir prašom eiti mokytis va ị tuos kursus..." (I3) ir kt. Rengiami teisès aktai bando ịtvirtinti principinę nuostatą dèl mokymosi nuoseklumo ir tęstinumo. Tai grindžiama tuo, jog „....atsitiktiniai, trumpalaikiai projektai, tai suaugusiajam žmogui - vieniems taip, bet didžiajai daliai tai nebūtų paveiku [...]“ (I5). 
Interviu duomenys rodo, kad neformaliajam suaugusiųjų švietimui skirtų lěšu yra pakankamai („,...daugybe ịvairiausių mokymų, țvairiausiose srityse [...] šimtai milijonų išleidžiama Lietuvoje“ (I3), „...ịstojus ị Europos Sąungą gauta tikrai daug lěšų, kurių nemaža dalis buvo skirta mokymuisi..." (I1) ir pan.), tačiau ne visada tos léšos ìsisavinamos tinkamai. Informantai pažymi, kad bèda ta, jog ne visada yra užtikrinama mokymų kokybė („,...visi pasidarè specialistai, visi moko, o kai pasižiūri kokybę, to kas daroma, kaip sakant, ịvairiai būna...“ (I3), ,...kiek mes iš tikrųjų turime tam parengtų specialistų, vẻlgi čia siejasi su neformaliojo kokybe, kiek tai vykdo žmonès, kurie turi tam turimų žinių ir kompetencijų“"(I1). Be to, neformaliajame suaugusiụjų švietime vykdoma neformaliojo suaugusiųjų mokymosi „...profesionalizacija, kitaip sakant, krypimas ị profesinį mokymąsi, neformalųji mokymąsi“ (I3), todèl nepakankamas dèmesys skiriamas neformaliajam neprofesiniam suaugusiųjų mokymui, suaugusiojo „....asmenybės tobulinimui...“ (I5), nors „....jeigu žmogus tobulèja kaip asmenybė, tai jisai ir toje darbo rinkoje, tam profesiniame gyvenime gali geriau save realizuoti“"(I5).

Tačiau Neformaliojo suaugusiųjų švietimo ịstatymo pakeitimo ịstatymo ịsigaliojimą stabdo tai, kad reikalingas finansavimas, „....reikalingos tam tikros lèšos...“ (I2), kurių valstybèje šiuo metu nèra, bei reikalingas kito teisès akto keitimas, nes dẻl įsigaliosiančios nuostatos reikètų keisti Darbo kodeksą, sudarant geresnes sąlygas darbuotojui, o ne darbdaviui, nes „...kiekvienas darbuotojas turi teisę ugdytis neformaliai ir darbdavys turètų ji išleisti, apmokẻdamas vidutinị darbo užmokestị" (I4).

Andragogai turi atkreipti demesị ị suaugusiojo mokymosi ypatumus, nes neformalusis suaugusiųjų švietimas skiriasi nuo neformaliojo vaikų švietimo. Atsižvelgiant ị suaugusiųjų mokymosi ypatumus turi būti rengiamos tokios mokymosi priemonès, kurios atitiktų tikslinę suaugusiųjų grupę. Priešingu atveju netinkamai parengtos mokymosi priemonės gali nepasiekti suaugusiụjų (,...priemonès turètų būti orientuotos į žmones, parašytos žmoniška kalba, ne kokiais ten aukštais filosofiniais dalykais [...] reikia pagalvoti apie tikslinę grupę“ (I5), „...laimi konkursą konsultacinès kompanijos [...] pradeda pasakoti „arabus“ tiems žmonèms [...] čia reikia labai paprastai, labai konkrečiais pavyzdžiais..."(I3).

Tyrimo duomenys patvirtina akivaizdžias edukologams gerai žinomas tiesas, kad suaugusysis mokosi, jei žino kodèl, kokiu tikslu jis mokosi (,...turi tikslą..." I2, I4), nes tai jam padeda „...išspręsti [...] problemą...“ (I3), kurią turi šiandien. Be to, besimokantysis suaugusysis tokiu būdu igyja žinių, kurias gali iš karto pritaikyti ir igyja patirties, kurios jis pats nori, o ne aplinka ji verčia mokytis („,...tie, kas nori mokytis, kas supranta jo reikšmę [...] jie randa finansavimą: arba patys finansuoja, arba gauna iš darbdavio, arba kreipiasi ị fondus...“ (I3), „....suaugusiojo niekas negali nei išmokyti, nei išugdyti, jis pats mokosi, ugdosi“ (I2), ,suaugusieji mokosi per savo patirti, per savo praktiką, jeigu jie išbando kažką, paliečia, pačiupinẻja, jie geriau tą supranta..." (I5).

Analizuojant interviu medžiagą, nustatyta, kad suaugusiųjų mokymasis susijęs su keliomis pagrindinèmis priežastimis: savo asmeninių poreikių tenkinimas, pras- 
mingos socialinès veiklos siekis bei profesinès kompetencijos ugdymas. Taigi, profesiniai poreikiai yra svarbus suaugusiojo motyvacijos mokytis veiksnys. Tyrimo duomenys rodo, kad „žmonès eina ị tokius mokymus, kurie jiems reikalingi geriau atlikti savo funkcijas, geriau dirbti, būti labiau konkurencingam, igyti darbą, neprarasti darbo ir t. t..." (I3). Asmeniniai poreikiai siejami daugiau su asmeniniais interesais ir pomegiais (,....asmeninių interesų, hobių, kultūrinio intereso...“ (I3), „...dalis žmonių nori mokytis dèl bendravimo, ieško socialinių kontaktų, bet ta dalis, aišku, yra nedidele ir tai dažniausiai vyresni žmonès" (I2). Šiuo aspektu svarbus kitas klausimas - kaip aktuali informacija pasiekia suaugusiuosius besimokančiuosius. Informantai teigia, kad informacijos sklaidai užtikrinti „...valstybiniu ir savivaldybiniu lygiu turi atsirasti informavimo ir konsultavimo tarnybos..." (I3). Turi būti parengta valstybès verslumo skatinimo programa, „...verslo skatinimo investicijos, kurių palūkanos yra labai mažos, specialiai pritaikytos pradedančiajam...“(I3), turi būti „...sukurta kitokia finansavimo sistema, ne per bankus..." (I3).

Akivaizdu, kad neformaliajam suaugusiųjų verslumo ugdymuisi reikalingos ịvairios mokymosi priemonès. Informantų teiraujantis apie šias priemones, ypač skirtas verslumo ugdymuisi, išryškejo, kad yra problemų su tokių priemonių prieinamumu. Viena opiausių problemų informantai nurodo tai, kad nacionaliniu lygiu nèra tokių mokymosi priemonių leidybos strategijos (,„...kas užsiima [...] mokymosi priemonių suaugusiajam gamyba, mokyklinių vadovèlių yra leidyklos, spaustuvės. Kas ką leidžia suaugusiųjų mokymuisi? Nulis" (I3). Tad šiuo atveju belieka nagrinèti tik pavienius atvejus, pripažistant, kad suaugusiųjų verslumo ugdymuisi skirtų priemonių néra daug. Dažniausia tai ịvairių projektų produktai, kurių kiekis taip pat yra ribotas ir, dažniausiai, platinamas tarp projekto dalyvių arba skiriama formaliajam suaugusiųjų mokymui („,...vieno projekto „Suaugusiųjų mokymo galimybių plètra: andragoginės literatūros portfelis" rezultatas yra vien apie dešimt vadovèlių..." (I2), „...tai metodiné medžiaga išleista mokykloms ir suaugusiųjų mokytojams [...] iš jos jie gali pasidaryti dalomąją medžiagą mokiniams“ (I3), „išleisti 6 leidiniai pagal parengtus andragoginius mokymo modulius, iš jų „Andragoginiai verslumo mokymo metodai“ (I5) ir pan.). Kaip pažymėjo informantai, dauguma mokymui/si skirtų priemonių nepasiekẻ nei knygynų, nei bibliotekų, todèl norinčiam susirasti tokias priemones reikia asmeniškai pažinoti tuos, kurie dalyvavo projektuose, kad galètų susipažinti ir pasinaudoti tų projektų medžiaga.

Informantai pažymi, kad ir „profesinio mokymo priemonių yra labai menkai...“ (I3). Didesnis profesinių mokymosi priemonių prieinamumas yra profesinių mokymo ịstaigų dalyviams, kur ịstaigos siekdamos užtikrinti profesinių mokymosi priemonių prieinamumą bendradarbiauja su verslo įmonėmis (,....bendravimas su verslo imonèmis, praktikų atlikimas tenai“ (I3). Mat darbdaviai kartais rengia „...seminarus [...] savo darbuotojams" (I1) arba ịsitraukia su kolektyvais ị ịvairias programas (pvz., „...per Žemès ūkio ministeriją, per lyderių programą [...] žemdirbiai labai smarkiai mokomi verslumo kompetencijų, kaip susikurti savo mažą versliuką, kaip išgyventi iš tų sūrių..." (I5). Žinoma, tokie mokymai turi savo projektus ịgyvendinant sukur- 
tus produktus, atskiras mokymosi priemones, kurias visi besimokantieji ateityje gali panaudoti savo ugdymosi procese. Kiek kita situacija su skaitmeninėmis mokymosi priemonėmis - jos dažniausiai būdamos virtualios, tarsi a priori yra laisvai prieinamos visiems norintiesiems, tačiau jų taip pat nèra „... tikslingai parengtų ...“ (I4), be to, yra „... bẻdų su skaitmeniniu raštingumu...“ (I2) suaugusiųjų, ypač vyresnio amžiaus.

\section{Išvados}

Suaugusiojo verslumo ugdymasis kaip kompetencija susijusi su sąmoningu kiekvieno asmens sprendimu ugdymo procese prisiimti ugdytojo funkcijas. Ivairiu mokslinių tyrimų rezultatų analizè rodo, kad, nepaisant ịvairių daugeliui suaugusiųjų būdingų ugdymąsi skatinančių veiksnių (profesinès kompetencijos tobulinimas, asmeninių poreikių realizacija, prasminga socialinè veikla ir pan.), neformaliajame suaugusiųjų švietime dažniau dalyvauja jaunesnio amžiaus suaugusieji, turintys aukštąj išsilavinimą, gaunantys didesnes pajamas bei dirbantys didžiuosiuose Lietuvos miestuose.

Neformaliojo suaugusiųjų verslumo ugdymasis bei tam reikalingų mokymosi priemonių prieinamumas susiję su neformaliojo suaugusiųjų švietimo situacija Lietuvoje. Atkreiptinas demesys, kad neformalusis suaugusiųjų švietimas iš esmès skiriasi nuo vaikų neformaliojo švietimo. Suaugusieji dažniausiai dalyvauja ugdymo procese suvokdami ugdymosi svarbą, todèl, atsižvelgiant ị suaugusiųjų mokymosi ypatumus, turi būti rengiamos tokios mokymosi priemonès, kurios atitiktų tikslinę suaugusiųjų grupę. Priešingu atveju netinkamai parengtos mokymosi priemonès gali nepasiekti suaugusiųjų.

Tyrimo duomenys rodo, kad viena opiausių problemų yra ta, kad nacionaliniu lygiu nèra mokymosi priemonių, skirtų verslumo ugdymui/si, leidybos strategijos. Igyvendinant ịvairius projektus ir programas sukurtos mokymosi priemonės nepasiekè nei knygynų, nei bibliotekų, todèl norinčiajam susirasti tokias priemones reikia asmeniškai pažinoti tuos, kurie dalyvavo projektuose, kad galètų susipažinti ir pasinaudoti tų projektų medžiaga.

\section{Literatūra}

Andragogu klausimai: praktiniai suaugusiuju mokymo aspektai. Vilnius: Lietuvos suaugusiųų švietimo asociacija, 2008.

Bitinas, B. Edukologijos terminija: kokybe ir problemos. Klaipèda: Klaipėdos universiteto leidykla, 2011.
Bukina, N. N. Stanovlenie sistemy neformalnogo obrazovanija sistemy vzroslykh. Chelovek i obrazovanie. 2006, 7.

Butviliené, J. Neformalusis suaugusiųjų švietimas: valstybinis ir privatus mokymo sektoriai. Acta Paedagogica Vilnensia. 2013, 30. 
Butvilienė, J. Suaugusiųjų neformaliojo švietimo socialinis kontekstas. Filosofija, Sociologija. 2011, 22(4).

Clair, R.; MacLachlan, K.; Tett, L. Educational entrepreneurs? Practitionerled action research and the formation of the professional adult literacies instructor. Studies In The Education Of Adults. 2009, 41(2).

Dačiulytè, R.; Tamulienè, J.; Zablackè, R. Mokymosi visą gyvenimą kompetencijų ugdymasis per neformalųji suaugusiųjų technologijų mokymąsi. Pedagogika. 2010, 97.

Dudaitè, J.; Žibènienè, G. Verslumo edukologijos studijų programą igyvendinančių dèstytojų samprata apie verslumą ir verslumo ugdymą. Socialinis darbas. 2012, 11(1).

Ekonominio raštingumo ir verslumo ugdymo strategija. Valstybès žinios. 2004, Nr. 96 -3555.

Gegieckienè, L.; Graikšienè, A. Verslumas. Vilnius: Ciklonas, 2009.

Giedrimienè, L. Neformalus suaugusių vartotojuc ugdymas. Studies in modern sočiety. 2012, 3(1).

Jelagaitè, A.; Lukoševičius, V. Mokinių verslumo ugdymas bendrojo ugdymo mokykloje: mokytojų požiūris. Pedagogika. 2011, 104.

Juozaitis, A. M. Pagrindinès kompetencijos andragogu profesineje veikloje. $P e$ dagogika. 2008, 89.

Kaimuose ir miestuose (gyventojų skaičius iki 30 000) gyvenančių suaugusiųjų mokymosi poreikiai, 2004 [žiūrèta 2014-01-22]. <http://www.upc.smm.lt/ svietimas/tyrimai/>.

Knowles, M. S.; Holton, E. F.; Swanson, R. A. Suaugęs besimokantysis: klasikinis požiūris ì suaugusiųų švietimą. Vilnius: Danielius, 2007.

Lietuvos Respublikos mokslo ir studiju įstatymas. Valstybès žinios. 2009, Nr. 54-2140.
Lietuvos Respublikos neformaliojo suaugusiųjų švietimo ịstatymas. Valstybès žinios. 1998, Nr. 66-1909.

Linkaitytè, G. M.; Žilinskaitė, L. Mokymosi visą gyvenimą idejos igyvendinimo perspektyva Lietuvoje. Pedagogika. 2008, 89.

Mokymosi visa gyvenima memorandumas. Vilnius: Lietuvos Respublikos švietimo ir mokslo ministerija, Lietuvos suaugusiųjų švietimo asociacija, 2001.

Mukhlaeva, T. V. Mezhdunarodnyj opyt neformalnogo obrazovanija, 2010 [interaktyvus]. [žiūrèta 2014-01-21]. $<$ http://inovrao.ru $>$.

Neformaliojo suaugusiujuc mokymosi sampratų analizė mokymosi visą gyvenimą kontekste, 2011 [interaktyvus]. [žiūrèta 2014-01-21]. <http://www. upc.smm.lt/svietimas/tyrimai/>.

Neformaliojo suaugusiųjų švietimo būklè ir gyventojų bei darbdavių požiūris i neformalųjị suaugusiųjų švietimą, 2005 [interaktyvus]. [žiūrèta 2014-01-21]. <http://www.upc.smm.lt/svietimas/ tyrimai/ $>$.

Neformaliojo suaugusiųjų švietimo plètra Lietuvoje: finansavimo alternatyvu analize, 2007 [interaktyvus]. [žiūrèta 2013-05-28]. <http://www.smm.lt/svietimo_bukle/docs/tyrimai/es/ VPVI\%20 studija\%20Neformalusis\%20svietimas. pdf $>$.

Neformaliojo suaugusiųjų švietimo plètra: Valstybès kontrolès valstybinio audito ataskaita, 2013 [interaktyvus]. [žiūrèta 2013-09-25]. <http://www.vkontrole.lt/ audito_ataskaitos.aspx?tipas $=2>$.

Plakhotnik, M.; Rocco, T. Implementing Writing Support Circles with Adult Learners in a Nonformal Education Setting: Priority, Practice, and Process. Adult Learning. 2012, 23(2).

Pruett, M. Entrepreneurship Education: Workshops and Entrepreneurial Intentions. Journal Of Education For Business. 2012, 87(2) 
Rutkienè, A.; Trepulè, E. Nuotolinis suaugusiųjų mokymas(is) mokymosi visą gyvenimą kontekste. Acta Paedagogica Vilnensia. 2009, 23.

Schmidt, S. W. Case Studies And Activities In Adult Education And Human Resource Development. Charlotte: Information Age Pub, 2010.

Strazdienè, G.; Garalis, A. Verslumas: ugdymo programos ir jų efektyvumo raiška. Organizaciju vadyba: sisteminiai tyrimai. 2006, 38.

Suaugusiųjų mokymasis Lietuvoje: aprèptis, poreikiai ir pasiūla, 2006 [interaktyvus]. [žiūrèta 2014-01-21]. <http:// www.suaugusiujusvietimas.lt/lt/suaugusiuju-svietimo-bukle/>.

Suaugusiųjų mokymosi motyvacija ir poreikiai Lietuvoje, Latvijoje, Estijoje ir Suomijoje, 2010 [interaktyvus]. [žiūrèta 2014-01-21]. <http://www.upc.smm. lt/svietimas/tyrimai/>.

Suaugusiųjų švietimo organizavimo bùklè savivaldybèse, 2006 [interaktyvus]. [žiūrèta 2014-01-21]. <http://www. upc.smm.lt/svietimas/tyrimai/>.

Suaugusiųjų tęstinio mokymo galimybių plètra mokymosi visą gyvenimą strategijos igyvendinimo kontekste, 2004 [inter- aktyvus]. [žiūrèta 2014-01-21]. <http:// www.upc.smm.lt/svietimas/tyrimai/>.

Taikomasis suaugusiųjų švietimo tyrimas, 2011 [interaktyvus]. [žiūrèta 2014-0121]. <http://www.suaugusiujusvietimas. lt/lt/suaugusiuju-svietimo-bukle/>.

Trakšelys, K. Suaugusiųjų švietimo tyrimų 2004-2011 metų analizè. Socialiniu mokslu studijos. 2012, 4(4).

Trečiojo amžiaus universitetų sistemos veiklos analizè, 2012 [interaktyvus]. [žiūrèta 2013-11-21]. <http://www. upc.smm.lt/ svietimas/tyrimai/>.

Turner, C. Veskite $i$ sekmę: kaip sukurti verslias organizacijas. Vilnius: Baltos lankos, 2005.

Valstybès pažangos strategija „Lietuvos pažangos strategija „Lietuva 2030“. Valstybès žinios. 2012, Nr. 61-3050.

Žemaitaitytè, I. Neformalusis suaugusiuju švietimas: pletros tendencijos dabartineje Europoje. Vilnius: MRU leidykla, 2007.

Župerka, A., Moksleivių verslumo ugdymo tobulinimo kryptys Lietuvoje. Verslas, vadyba ir studijos. Vilnius: Technika, 2009.

\title{
THE ACCESSIBILITY OF LEARNING TOOLS FOR NON-FORMAL ADULT SELF-EDUCATION IN ENTREPRENEURSHIP
}

\author{
Romas Prakapas, Jolanta Devenytè \\ Mykolas Romeris University, Lithuania
}

Summary. The article analyses the phenomenon of non-formal adult self-education in entrepreneurship, given that in Lithuania studies related to (self-)education in entrepreneurship mostly focus on formal education. Purposeful research which has been carried out in Lithuania for a decade into adult education has identified major problems (e.g., financing, ensuring quality, educators' competences, etc.), which are mainly linked only to the external factors in the process of education; whereas the analyses of the 
educational activities reveal a need for research into self-education of adults and the conditions created to facilitate such learning. One of the conditions is the accessibility of tools for adult self-education in entrepreneurship. The aim of the article is to reveal the accessibility of learning tools for non-formal adult self-education in entrepreneurship in Lithuania. The research subject is the accessibility of learning tools for adult selfeducation in entrepreneurship.

The article presents the findings of the empirical research carried out in October through November of 2013. The research was carried out using the method of oral survey (interview). The instrument of the research was based on document and literature analysis which helped to determine the situation in non-formal adult education in Lithuania. The participants of the research $(n=5)$ were andragogues actively engaged in non-formal adult education and performing purposeful scientific research into adult education.

At the end of the article, the main research findings and conclusions are presented: younger adults with higher education and higher income working in the largest towns of Lithuania are more frequently engaged in non-formal adult education; adults who engage in the process of education usually understand the importance of self-education, therefore, the peculiarities of adult learning should be taken into consideration in order to develop learning tools which match the target group of adults; one of the major issues is the lack of a national strategy on the development and publishing of learning tools for (self-) education in entrepreneurship.

Keywords: non-formal adult education, learning tools, entrepreneurship selfeducation.

Romas Prakapas, Mykolo Romerio universiteto Socialinių technologijų fakulteto Edukologijos ir socialinio darbo instituto docentas, socialinių mokslų (edukologija) daktaras. Mokslinių tyrimų kryptys: verslumo ugdymas, tyrimų metodologija.

Romas Prakapas, Doctor of Social Sciences (Educational Science), Associate Professor at Mykolas Romeris University, Faculty of Social Technologies, Institute of Educational Sciences and Social Work. Scientific interests: entrepreneurship education, research methodology.

Jolanta Devenytė, socialinių mokslų (edukologija) magistrè. Mokslinių tyrimų kryptys: suaugusiųjų švietimas, verslumo ugdymas.

Jolanta Devenytė, Master Deegre of Social Sciences (Educational Science). Scientific interests: adult education, entrepreneurship education. 